THE LONDON SCHOOL

OF ECONOMICS AND

POLITICAL SCIENCE

\title{
The internationalization of economic history: A puzzle
}

\author{
Johan Fourie \\ Stellenbosch University \\ Leigh Gardner \\ LSE, Stellenbosch University
}




\title{
The internationalization of economic history: A puzzle
}

\author{
Johan Fourie ${ }^{1}$ \\ Stellenbosch University \\ Leigh Gardner ${ }^{2}$ \\ LSE, Stellenbosch University
}

\begin{abstract}
The internationalization of economic history is everywhere except in the publication outputs. Using a new dataset of publications in the top four economic history journals, we investigate this puzzle and attempt to explain why relatively few papers on and from developing countries are published in top journals despite the growing internationalization of economic history more broadly. We find little evidence to suggest that this is due to a bias against papers on developing country topics and by developing country authors. Developing country papers and authors also do not perform worse in citation analyses. Authors from developing countries, it seems, are less productive, or discouraged from submitting their papers to top quality journals, choosing instead local journals. This journal aims to reduce this disparity.
\end{abstract}

JEL Codes: A11, A14

Keywords: internationalization, publication output, developing countries, citation analysis, journals

Acknowledgements: The authors would like to thank Joerg Baten, Stephen Broadberry, Latika Chaudhary, Claude Diebolt, Ewout Frankema, Se Yan and Jan Luiten van Zanden for valuable comments and suggestions on an earlier version, and Jan Greyling for excellent research assistance.

\footnotetext{
${ }^{1}$ Department of Economics, Stellenbosch University, South Africa. E-mail: johanf@sun.ac.za.

${ }^{2}$ Department of Economic History, London School of Economics, UK, and Department of Economics, Stellenbosch University, South Africa.
} 


\section{Introduction}

Economic history used to be written primarily about, and by, people from the industrialized world. The motive behind most economic history research until recently was to understand the process of industrialization in the nineteenth century and the meteoric rise in living standards that followed. As a result, papers in economic history journals have tended to restrict their analysis to Europe and North America.

Part of this story has changed, for a variety of reasons. The recent economic expansion of China, India and other developing countries has shifted scholarly attention not only to these rapid changes but also to the earlier periods of seeming stagnation. Research on the Great Divergence (Pomeranz 2000; Allen 2001; Broadberry \& Gupta 2006) has debated the relative position of European nations in the world economy, informed by new research on the economic histories of India and China that suggest greater affluence in these countries than was previously assumed. Studies of Africa and Latin America have examined institutional constraints to economic growth (Acemoglu et al. 2001; Acemoglu \& Robinson 2010; Engerman \& Sokoloff 2011), or historical reasons for the persistence of poverty (Nunn 2008; Huillery 2009; Michalopoulos \& Papaioannou 2014).

Summaries of developments in the field have emphasized this expansion of geographical reach. Reviewing the state of economic history research, Baten and Muschallik (2012, 93) note that 'economic history has developed into a truly global discipline over the past two decades'. Di Vaio et al. (2012, 93), investigating the citation success of economic history journals, suggest that 'while economic history may have declined as a discipline in Anglo-Saxon countries, the interest in economic history topics seems to be on the increase elsewhere'.

There is much evidence to support this interpretation. Some of the most influential recent publications in economics have been on economic history topics, often in non-Western settings. Consider, for example, Acemoglu et al.'s 'Colonial origins of comparative development,' published in the American Economic Review in 2001. Using settler mortality as instrument, these authors argue that 
the type of early institutions that countries adopted explains modern-day differences in levels of development. The paper currently ranks 39th in the list of all-time most cited papers in economics, and has more than 6800 Google Scholar (GS) citations. ${ }^{1}$ AJR's contribution inspired a new generation of economics graduates to work on economic history topics. Notable among these new authors' publications are Nunn's 'The long-term effects of Africa's slave trades' (2008) published in the Quarterly Journal of Economics, with 364 GS citations, and Dell's 'The persistent effects of Peru's mining mita' (2010), published in Econometrica, with 178 GS citations. This newly awakened interest in the long-run causes of development has continued, as reflected in two recent publications in leading economics journals: Michalopoulos \& Papaioannou (2013), which combines information on the spatial distribution of ethnicities before colonization with contemporary economic performance as proxied by satellite images of light density, and Spolaore \& Wacziarg (2013), which investigates two channels - biology (via genetic or epigenetic transmission) and culture (via behavioural or symbolic transmission) - through which intergenerationally transmitted characteristics may affect economic development.

Around the same time that economists turned to history to explain countries' divergent development trajectories, historian Kenneth Pomeranz posited that Western Europe only began to diverge from China during the early nineteenth century, much later than had previously been thought (Pomeranz 2000). The Great Divergence hypothesis, together with the renewed interest of economists, spurred economic historians to collect series on prices, wages and incomes not only in Western Europe but especially outside the Western world. While economics and history journals have attracted excellent work (Galor \& Mountford 2006; Shiue \& Keller, 2007), it is little surprise that the most significant contributions were published in the leading economic history journals: consider, for example, Robert Allen's 'The great divergence in European wages' (2001), published in Explorations in Economic

\footnotetext{
${ }^{1}$ RePEc (research papers in economics) list of most cited papers in economics. 'Colonial origins' has 1332 citations, according to the RePEc citation calculator. RePEc and Google Scholar citation information correct as of 10 February 2014.
} 
History, which is the most cited paper in any of the top four economic history journals (since 1998), ${ }^{2}$ while Broadberry and Gupta's 'The early modern great divergence' (2006), published in the Economic History Review, is the only paper in a list of the top 15 most-cited papers, as ranked by Google Scholar, with a non-Western theme.

The rising scholarly interest in the developing world has been supported by academic societies' choice of conference themes, awards and host venues. For a paper on African wages, Ewout Frankema and Marlous van Waijenburg shared the 2013 Arthur H. Cole prize, awarded for the best paper published in the Journal of Economic History, with Dan Bogart and Latika Chaudhary for their paper on Indian railways (Frankema \& Van Waijenburg 2012; Bogart \& Chaudhary 2013). Stellenbosch, South Africa, hosted the World Economic History Congress 2012, a triennial event organized by the International Economic History Association, and in 2015 the event will move to Asia (Kyoto, Japan). In preparation for the South African event, Baten and Muschallik (2012) undertook a survey of the global interest in economic history, measuring the number of economic historians per country. The findings, reported in Table 1, were startling: only $40 \%$ of economic historians were based in the Western world, and more than a third of all economic historians were based in Asia. The large share of Asia in the global count is a consequence of the popularity of economic history in Japan, which has an estimated 1340 scholars working in the field. But even if we exclude Japan from this list, 42.6\% of all economic historians are based in developing countries (Baten \& Muschallik, 2012, 98-99, Table 2). Clearly, economic history has become a global discipline.

Table 1: Number of economic historians by region

\begin{tabular}{|c|c|c|}
\hline & Number & Share of world \\
\hline Africa & 89 & $1.0 \%$ \\
\hline
\end{tabular}




\begin{tabular}{lrr} 
Asia & 2933 & $33.8 \%$ \\
Australasia & 50 & $0.6 \%$ \\
Eastern Europe/Russia & 693 & $8.0 \%$ \\
Great Britain & 686 & $7.9 \%$ \\
Latin America & 1123 & $13.0 \%$ \\
Middle East & 218 & $2.5 \%$ \\
North America & 814 & $9.4 \%$ \\
Western Europe & 2060 & $23.8 \%$ \\
\hline \hline
\end{tabular}

Source: Baten and Muschallik (2012); own calculations

Not only are there many economic history scholars based outside the Western world, but interest in the economic histories of developing regions appears to be on the increase too. The number of paper submissions dealing with the non-Western world has grown rapidly: Jean-Laurent Rosenthal, editor of the Journal of Economic History, reports that between 2008 and 2012 paper submissions on topics outside North America, Western Europe and Australasia increased by 86\%, while submissions from the traditional North American and Western European countries remained stable, or even declined. According to Rosenthal, 'Africa, Asia, Australia and New Zealand, Latin America and the Middle East seem to be making substantial gains’' (Rosenthal 2013, 279-280).

\section{Trends in journal publications}

Yet, to misquote Robert Solow, one can see the internationalization of economic history everywhere but in the research publications. Rosenthal was referring to paper submissions, but a completely different picture emerges when we consider published papers. To see this picture, we counted the number of papers published by the Journal of Economic History by region of interest between 2009 
and $2013 .^{3}$ In contrast to the $86 \%$ growth rate in journal submissions to JEH from non-Western countries (from a total of 22 to 41 submissions), the number of papers on non-Western topics published declined from 9 to 8 .

These trends may simply reflect the preferences of the editors of the Journal of Economic History. To test whether this is true, we surveyed the top four economic history journals as ranked by Di Vaio and Weisdorf (2010) and categorized each paper in all the volumes published from January 1998 to December 2013 according to region of interest. Figure 1 provides an annual breakdown of these regions. Despite the increase in the number of papers published in the four journals over the past two decades, there has been little change in the share of papers that deal with developing countries. The lack of developing country coverage is clearly not journal specific.

[Figure 1 here]

What causes this dearth of published papers on developing country topics in the leading economic history journals? Perhaps it is simply that these papers are of lower quality. For example, most researchers in the US present working papers at seminars and conferences before submitting them to a journal. This is probably more difficult for authors residing in developing countries. This must influence the probability of a rejection versus revise and resubmit. To test this hypothesis, Table 2 lists the regional breakdown of papers received versus papers accepted, again, because of data limitations, only for the Journal of Economic History. There seems to be some bias against papers on developing country topics in the acceptance rates of the JEH: while papers with a Latin American focus perform better than Western European (26\%), British (22\%) and even North American submissions (39\%), African and Eastern European papers score very low on acceptance rates (13\%). Three of the five developing regions are at the bottom of the list. If a quality bias does exist, it is not

\footnotetext{
${ }^{3}$ We assumed a one-year lag in publication time.
} 
universal for all developing regions; in our sample, it is against papers with an Africa, Middle East and Eastern Europe/Russia focus.

Table 2: Comparison between papers received and papers published, by region of interest

\begin{tabular}{lrrr}
\hline \hline & $\begin{array}{l}\text { Received } \\
(2008-\end{array}$ & $\begin{array}{l}\text { Published } \\
(2009-\end{array}$ & $\begin{array}{l}\text { Share } \\
\text { published }\end{array}$ \\
\hline Africa & $2013)$ & 3 & $13.0 \%$ \\
Asia & 38 & 10 & $26.3 \%$ \\
Australasia & 4 & 1 & $25.0 \%$ \\
Eastern Europe/Russia & 23 & 3 & $13.0 \%$ \\
Great Britain & 81 & 18 & $22.2 \%$ \\
Latin America & 30 & 12 & $40.0 \%$ \\
Middle East & 19 & 4 & $21.1 \%$ \\
North America & 171 & 66 & $38.6 \%$ \\
Western Europe & 159 & 41 & $25.8 \%$ \\
NA & 15 & 4 & $26.7 \%$ \\
\hline \hline
\end{tabular}

Source: Rosenthal (2013, 281); own calculations

Another reason for the low level and growth of papers published with a developing country topic is that historical data is often limited, or less readily accessible, in these regions. ${ }^{4}$ Perhaps it is this reason that work on developing country topics published by Nunn, Dell and others in highly-ranked economics journals has featured innovative quantitative techniques designed to cope with limitations in the quality and quantity of available data. Their work, however, tend to be published in economics journals, and we may therefore expect that these journals carry a greater share of papers from developing regions. To test this, we classified all the economic history papers published between 2000

\footnotetext{
${ }^{4}$ There are exceptions, of course. See Fourie (2014).
} 
and 2013 in one of the leading economics journals, the American Economic Review, by region of interest. ${ }^{5}$ Only $9.2 \%$ of the historically oriented economics papers concerned countries outside North America and Western Europe, mirroring the percentage of these papers in economic history journals. This therefore does not seem to be the explanation.

A third possibility is that papers on developing country themes find their way to lower-ranked economic history journals, such as the Journal of Iberian and Latin American Economic History, or the Indian Economic and Social History Review. While it is likely that these journals are populated with histories of developing regions, it is also likely that several other lower-ranked economic history journals - such as the Scandinavian Economic History Review, the Low Countries Journal of Social and Economic History, the French Journal of Quantitative Economic History, the German Historical Social Research and the Australian Economic History Review - publish predominantly papers with a Western theme.

Not only are developing countries as topic underrepresented in the leading economic history journals, but articles by economic historians based in developing countries are almost entirely absent. Consider again Baten and Muschallik's count from survey estimates: 43\% of economic historians are based in the developing world. Yet, as Figure 2 shows, when we count authors' affiliations at time of publication by country, and weight them by the number of authors per paper, we find a remarkably different story: only $2.2 \%$ of all authors published in the top four economic history journals were affiliated to universities in the developing world (the full list is available in the appendix.) The scarcity of publications by economic historians in developing countries is perplexing.

[Figure 2 here]

\footnotetext{
${ }^{5}$ We found 141 articles in the AER between 2000 and 2013 with 'history' listed as subject.
} 
One possible explanation for this shortfall could be that papers with a developing country topic or papers whose authors are based in developing countries get fewer citations. By not accepting papers on these topics or by authors from these countries, editors would therefore be making a rational decision. We test this hypothesis with data we collected on the 1695 papers published in the top four economic history journals since 1998. Table 3 rejects the hypothesis. In specifications (1) and (2), we OLS regress the region covered by each paper on the number of GS citations earned by that paper in February 2014. In specifications (3) and (4), we test whether a paper has an author from a developing country on the number of GS citations. We also add a few additional explanatory variables. 'PaperID' ranks the paper by its position in the journal. Papers near the beginning of each issue tend to get cited more frequently. 'Comment' is a dummy variable that is 1 if the paper was a short note or response to an earlier paper. Comments receive on average 12 fewer citations than standard papers. We include year fixed-effects in all four specifications, and in specifications (2) and (4) we also add journal fixedeffects.

Table 3: Partial correlation between developing country topics, developing country authors and GS citations

\begin{tabular}{lllll}
\hline \hline & $(1)$ & $(2)$ & $(3)$ & $(4)$ \\
\hline PaperID & $-1.242^{* * *}$ & $-1.515^{* * *}$ & $-1.364^{* * *}$ & $-1.578^{* * *}$ \\
& $(-4.27)$ & $(-5.14)$ & $(-4.61)$ & $(-5.24)$ \\
Comment & $-12.13^{* *}$ & $-11.60^{* *}$ & $-13.63^{* *}$ & $-12.41^{* *}$ \\
Western Europe & $(-2.91)$ & $(-2.80)$ & $(-3.21)$ & $(-2.93)$ \\
& $5.906^{* *}$ & $4.580^{*}$ & & \\
Eastern Europe/Russia & $(3.11)$ & $(2.35)$ & & \\
& -6.677 & -8.591 & & \\
North America & $(-1.48)$ & $(-1.91)$ & & \\
& 0.839 & $-4.603^{*}$ & & \\
& $(0.45)$ & $(-2.16)$ & &
\end{tabular}




\begin{tabular}{|c|c|c|c|c|}
\hline \multirow[t]{2}{*}{ Latin America and Caribbean } & 5.179 & 0.335 & & \\
\hline & $(1.24)$ & $(0.08)$ & & \\
\hline \multirow[t]{2}{*}{ Asia } & -1.918 & -4.977 & & \\
\hline & $(-0.57)$ & $(-1.47)$ & & \\
\hline \multirow[t]{2}{*}{ Africa } & 3.530 & 3.111 & & \\
\hline & $(0.60)$ & $(0.53)$ & & \\
\hline \multirow[t]{2}{*}{ Australasia } & -4.863 & -6.706 & & \\
\hline & $(-0.58)$ & $(-0.80)$ & & \\
\hline \multirow[t]{2}{*}{ Global } & $33.22 * * *$ & $31.47 * * *$ & & \\
\hline & $(8.49)$ & $(8.01)$ & & \\
\hline \multirow[t]{2}{*}{ Middle East } & $18.32 * *$ & $13.48^{*}$ & & \\
\hline & $(2.73)$ & $(2.01)$ & & \\
\hline Year fixed-effects & Yes & Yes & Yes & Yes \\
\hline Journal fixed-effects & No & Yes & No & Yes \\
\hline \multirow[t]{2}{*}{ Dev author } & & & -4.379 & -4.888 \\
\hline & & & $(-0.68)$ & $(-0.76)$ \\
\hline \multirow[t]{2}{*}{ Constant } & 5.736 & 5.516 & $8.557 * *$ & 6.146 \\
\hline & $(1.87)$ & $(1.74)$ & $(2.90)$ & $(1.94)$ \\
\hline $\mathrm{N}$ & 1695 & 1695 & 1695 & 1695 \\
\hline Adj. R-squared & 0.194 & 0.210 & 0.153 & 0.167 \\
\hline
\end{tabular}

Notes: The dependent variable is GS citations. Britain is the control region. Dev author is a dummy variable that equals 1 if an author is based in a developing country.

Our variables of interest in specifications (1) and (2) are the region dummies. We find little evidence that papers on developing countries attain lower rankings than papers on developed countries; with Britain as control group, no region has a lower citation rating that is statistically significant. Eastern Europe/Russia is the worst-performing region, although not statistically different from Britain. In contrast, papers on the Middle East perform much better, receiving, on average, 13 more citations 
than papers on Britain. Papers on Latin America and the Caribbean and Africa appear to have positive coefficients, although not statistically significant. There is certainly no evidence that papers with developing country themes perform worse than papers with a Western theme. Papers that have a global theme according to our definition, i.e. that cover multiple countries spread across more than three regions, perform very well on citation analysis, with a large, significant coefficient of above 30 additional citations. In many of these papers, developing countries feature prominently, further strengthening the case that papers about developing countries do not underperform papers on developed countries.

Further, papers by a developing country author do not seem to perform any worse. While the coefficient for 'Dev author' is negative, it is not statistically significant at the $10 \%$ level. On the basis of this evidence, there is certainly little justification for a systematic bias against developing country authors.

The puzzle as to why so few papers with developing country topics and authors are published is not unique to economic history. In a survey of papers published in empirical economics, Das et al. (2013) find that, particularly in top-ranking economics journals, authors of published papers are significantly more likely to be from US institutions, writing about the US. Similarly, Chan et al. (2007) find that the authors of an 'overwhelming' share of publications in top journals in finance come from US institutions, and that, as in economic history, the most productive countries in terms of research are the US, UK, Canada and Australia. Both studies find that higher per capita incomes and the use of English have a significant and positive effect on research outputs.

These two variables help explain much of the difference in research output between developed and developing country institutions. It has long been recognized that in African universities, for example, limited research funding and infrastructure, poor remuneration and heavy teaching loads make increasing research output extremely difficult (Coker-Kolo \& Darley 2013, 16). These problems have been exacerbated by several factors. One has been rapidly increasing enrolments in African universities since the end of the colonial period, which has continued even through periods of 
economic crisis (Atuahene 2011). Sawyerr (2004) notes that the pace of increasing enrolments and the diversification of student demand for a range of degree and training programmes have put pressure on already scarce resources. The poor salaries paid to academics at African universities have contributed to the rise of 'third sector' think-tanks affiliated with universities where many African scholars conduct research in exchange for additional remuneration (Coker-Kolo \& Darley 2013). These factors affect not only the initial writing and submission of papers but also the authors' ability to follow up on suggested revisions through the peer review process. They have also influenced scholars' locations poor conditions of employment have meant that African academics who trained abroad in the 1970s and 1980s often chose to remain abroad (Sawyerr 2004, 30). It is likely that at least some of the published research on the economic history of developing regions is by scholars from the diaspora.

Asian universities have been less constrained by funding shortages. Expenditure on research has increased rapidly in recent years, with some elite universities rivalling universities in the UK and Europe, even if the level of expenditure still falls below that of the US. According to Mohrman (2013), while the number of publications by scholars from Asian universities has increased, they still perform relatively poorly in terms of citations. The top performers in terms of international publications in economics tend to be in relatively rich economies such as Hong Kong, Japan, Korea, Singapore and Taiwan (Jin \& Hong 2008, 81). The limited impact of Asian publications may be partly explained by their publication in local journals in languages other than English. In Japan, for example, the research published by the large body of economic historians identified by Baten and Muschallik (2012) has primarily been published in Japanese language.

Differences in academic traditions and career progression incentives may be an important reason for the limited publication of work on developing countries. The increasingly quantitative nature of work published in the core economic history journals may discourage submissions from scholars based in history departments and business schools whose work may rely on more qualitative evidence. Economic history in North America may have increasingly shifted to economics departments, but this is not necessarily true in all regions, and just over a third of Batin and Muschallik’s (2012) survey respondents identified themselves as primarily historians. Different disciplinary affiliations and 
national traditions may lead to diverse ways of framing research questions which make it more difficult for scholars from non-Western countries to publish in the top four journals. Finally, the career rewards of publishing in international journals may not in all cases be sufficiently compelling to incentivise authors to submit their work there. Network effects may also be important. Future research could investigate, for example, the impact of conference attendance on publication output. It can be difficult, but not impossible, for developing country authors to become part of international networks in their field owing to a variety of factors, from language ability to the cost of travel.

The increasing globalization of the academic community may bring change in all of these factors. Universities in the developing world increasingly need to compete with institutions in the US and in Europe for faculty, students and status in highly publicized university rankings. In economic history in particular, the growing body of comparative and internationally collaborate research incorporating work on countries outside the industrialized 'core' will drive demand for research to be published in a common language. The ability to circulate research in draft form online may facilitate the building of networks even without travel to conferences. Further, the introduction of greater rewards for publishing in international journals, as has happened in several South African universities, may increase the rate of submission and also the authors' willingness to undergo the sometimes lengthy reviewing and revision processes required by competitive journals. In South Africa, the rewards include financial resources to fund conference participation, which can help to connect these scholars to the network. The outcomes of these developments will become clearer as time passes. There is, however, the need for a deeper investigation of the factors that determine research output in economic history. Identifying the reasons for the low levels of output on developing country topics and from developing country authors, and the slow rate of increase, can inform attempts by international societies to engage with these regions and encourage their research. 


\section{The role of Economic History of Developing Regions}

Another way to encourage research on and from developing countries is to expand the available publication space. Since 2010, EHDR (formerly the South African Journal of Economic History) has published research articles with a developing country theme. The papers are exclusively developing country oriented and $44.6 \%$ of the authors published by this journal to date, weighted by number of authors, are based in developing countries - just above the share of $42.6 \%$ calculated by Baten and Muschallik (2012). While a large proportion of them are based in South Africa, articles by authors based in China, Taiwan, Uruguay, Mexico and India have also appeared in the journal.

EHDR compares well to the top journals in the field. Using Google Scholar, we compare the average number of citations per paper for the top four journals between 1998 and 2012 (at the time of publication, 2013 paper citations were close to zero), Cliometrica (an English-language journal launched in 2007) and EHDR. Figure 3 shows the results.

[Figure 3 here]

While the number of papers published in this journal is still too small to warrant a careful econometric analysis, the number of citations generated in 2010 - more than those for the Economic History Review, the European Review of Economic History and Cliometrica - does suggest that a market exists for the economic histories of developing countries.

A new editorial team was appointed in January 2014. We are looking forward to working with some of the leading economic historians of developing regions: Ewout Frankema (Wageningen University, The Netherlands), Se Yan (Peking University, China), Alfonso Herranz Loncan (University of Barcelona, Spain), Latika Chaudhary (Scripps College, USA) and Alex Klein (University of Kent, 
UK). We believe that EHDR is well positioned to take advantage of the opportunities of a largely untapped market, and we look forward to building a community of scholars. 


\section{References}

Acemoglu, D \& Robinson, J, 2010. Why is Africa poor? Economic History of Developing Regions 25, 21-50.

Acemoglu, D, Johnson, S \& Robinson, J, 2001. The colonial origins of comparative development: An empirical investigation. American Economic Review 91, 1369_ 1401.

Allen, R, 2001. The great divergence in European wages and prices from the middle ages to the first world war. Explorations in Economic History 38, 411-447.

Atuahene, F, 2011. Re-thinking the missing mission of higher education: An anatomy of the research challenge of African universities. Journal of Asian and African Studies 46, $321-341$

Baten, J \& Muschallik, J, 2012. The global status of economic history. Economic History of Developing Regions 27, 93-113.

Bogart, D \& Chaudhary, L, 2013. Engines of Growth: The Productivity Advance of Indian Railways, 1874-1912. Journal of Economic History 73, 339-370.

Broadberry, S \& Gupta, B, 2006. The early modern great divergence: Wages, prices and economic development in Europe and Asia, 1500-1800. Economic History Review 59, 2-31.

Chan, KC, Chen, CR \& Lung, PP, 2007. One-and-a-half decades of global research output in finance: 1990-2004. Review of Quantitative Financial Accounting 28, 417-439.

Coker-Kolo, D \& Darley, WK, 2013. The role for African universities in a changing world. Journal of Third World Studies 30, 11-38.

Das, J, Do, Q, Shaines, K \& Srikant, S, 2013. U.S. and them: The geography of academic research. Journal of Development Economics 105, 112-130.

Dell, M, 2010. The persistent effects of Peru's mining mita. Econometrica 78, 1863-1903.

Di Vaio, G \& Weisdorf, J, 2010. Ranking economic history journals: A citation-based impact-adjusted analysis. Cliometrica 4, 1-17.

Di Vaio, G, Waldenstrom, D \& Weisdorf, J, 2012. Citation success: Evidence from economic history journal publications. Explorations in Economic History 49, 92-104.

Engerman, S \& Sokoloff, K, 2011. Economic Development in the Americas since 1500: Endowments and Institutions. Cambridge University Press, Cambridge, MA.

Fourie, J, 2014. The Quantitative Cape: A Review of the New Historiography of the Dutch Cape Colony. South African Historical Journal. In press. 
Frankema, E \& Van Waijenburg, M, 2012. Structural impediments to African growth? New evidence from real wages in British Africa, 1880-1965. Journal of Economic History 72, 895-926.

Galor, O \& Mountford, A, 2006. Trade and the Great Divergence: The family connection. American Economic Review 96, 299-303.

Huillery, E, 2009. History matters: The long-term impact of colonial public investments in French West Africa. American Economic Journal: Applied Economics 1, 176-215.

Jin, CJ \& Hong, J-H, 2008. East Asian rankings of economics departments. Journal of Asian Economics 19, 74-82.

Michalopoulos, S \& Papaioannou, E, 2013. Pre-colonial ethnic institutions and contemporary African development. Econometrica 81, 113-152.

Michalopoulos, S \& Papaioannou, E, 2014. National institutions and sub-national development in Africa. Quarterly Journal of Economics 129, 151-213.

Mohrman, K, 2013. Are Chinese universities globally competitive? The China Quarterly 215, 727-743.

Nunn, N, 2008. The long-term effects of Africa's slave trades. Quarterly Journal of Economics 123, 139-176.

Pomeranz, K, 2000. The Great Divergence: China, Europe, and the Making of the Modern World Economy. Princeton, Princeton University Press.

Rosenthal, J-L, 2013. Editor's notes. Journal of Economic History 73, 279-286.

Sawyerr, A, 2004. Challenges facing African universities: Selected issues. African Studies Review 47, 1-59.

Shiue, CH \& Keller, W, 2007. Markets in China and Europe on the eve of the Industrial Revolution. American Economic Review 97, 1189-1216.

Spolaore, E \& Wacziarg, R, 2013. How deep are the roots of economic development? Journal of Economic Literature 51, 325-369.

\section{Appendix}

Table A1: Share of author affiliations published in the top four economic history journals, by country

\begin{tabular}{llll}
\hline \hline Region & Share & Region & Share \\
\hline Argentina & $0.24 \%$ & Mexico & $0.06 \%$
\end{tabular}




\begin{tabular}{llll} 
Australia & $1.48 \%$ & Netherlands & $3.08 \%$ \\
Austria & $0.12 \%$ & New Zealand & $0.29 \%$ \\
Belgium & $0.94 \%$ & Nigeria & $0.06 \%$ \\
Brazil & $0.12 \%$ & Norway & $0.47 \%$ \\
Bulgaria & $0.06 \%$ & Poland & $0.00 \%$ \\
Canada & $4.25 \%$ & Portugal \\
Chile & $0.06 \%$ & Russia & $0.29 \%$ \\
China & $0.24 \%$ & Singapore & $0.29 \%$ \\
Colombia & $0.18 \%$ & South Africa & $0.06 \%$ \\
Denmark & $1.36 \%$ & South Korea & $0.18 \%$ \\
Finland & $0.29 \%$ & Spain & $1.00 \%$ \\
France & $1.84 \%$ & Sweden & $4.13 \%$ \\
Germany & $4.32 \%$ & Switzerland & $2.24 \%$ \\
Greece & $0.18 \%$ & Taiwan & $0.94 \%$ \\
Iceland & $0.06 \%$ & Turkey & $0.12 \%$ \\
India & $0.12 \%$ & UK \& Ireland & $0.41 \%$ \\
Israel & & USA & $28.48 \%$ \\
Italy & $0.88 \%$ & \\
\hline \hline
\end{tabular}




\section{Figures}

Figure 1: Regional composition of publication output topics for the top four journals, 19982013

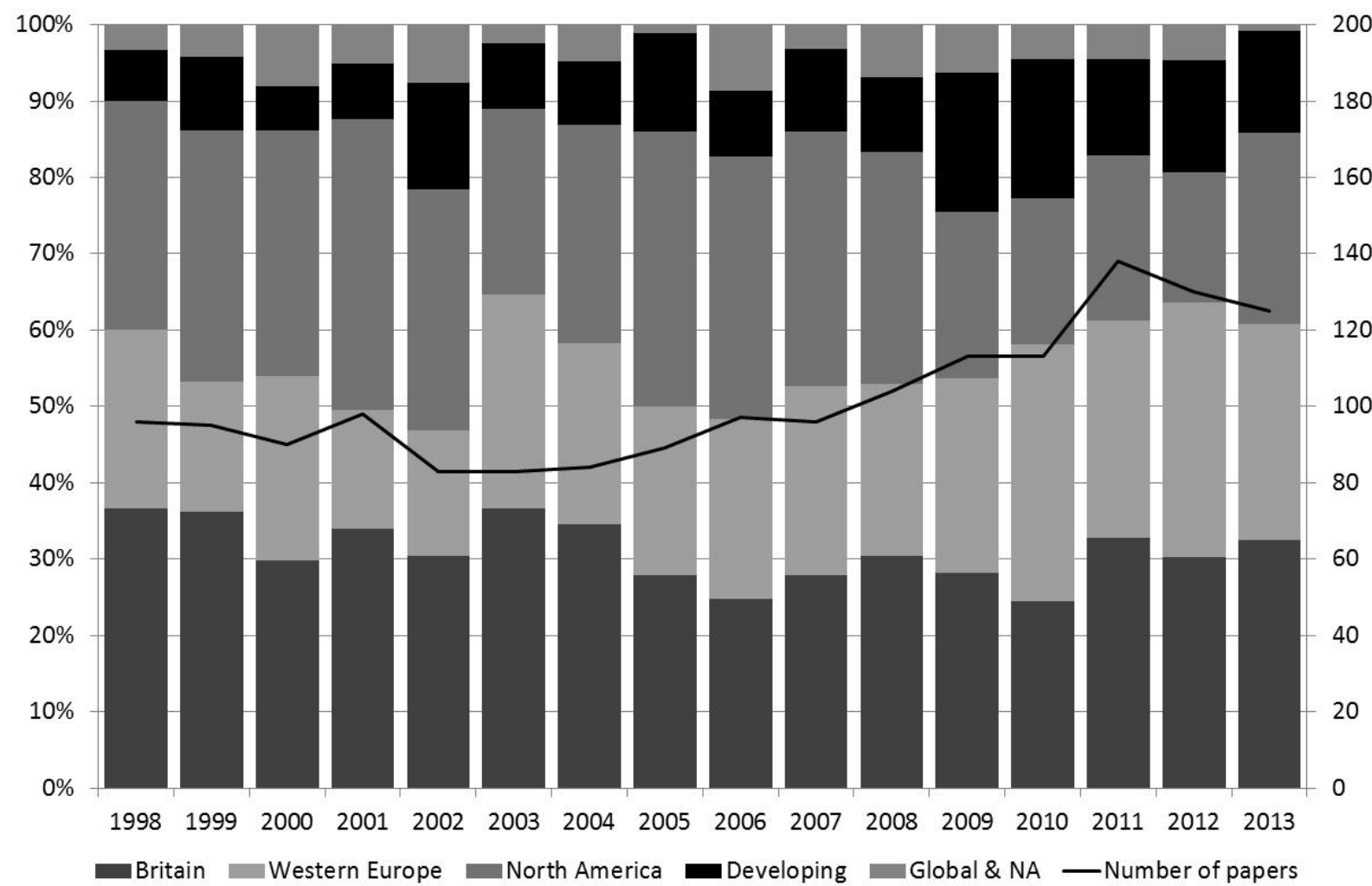

Notes: Share of articles that pertain to each region. As judged by the author. Western Europe includes Scandinavian countries. North America only includes USA and Canada. Each paper may have more than one region of interest, but not more than three. If more than three regions apply, the region is called 'global'. NA refers to papers with no specific setting. 
Figure 2: Author affiliation by country, weighted by number of authors

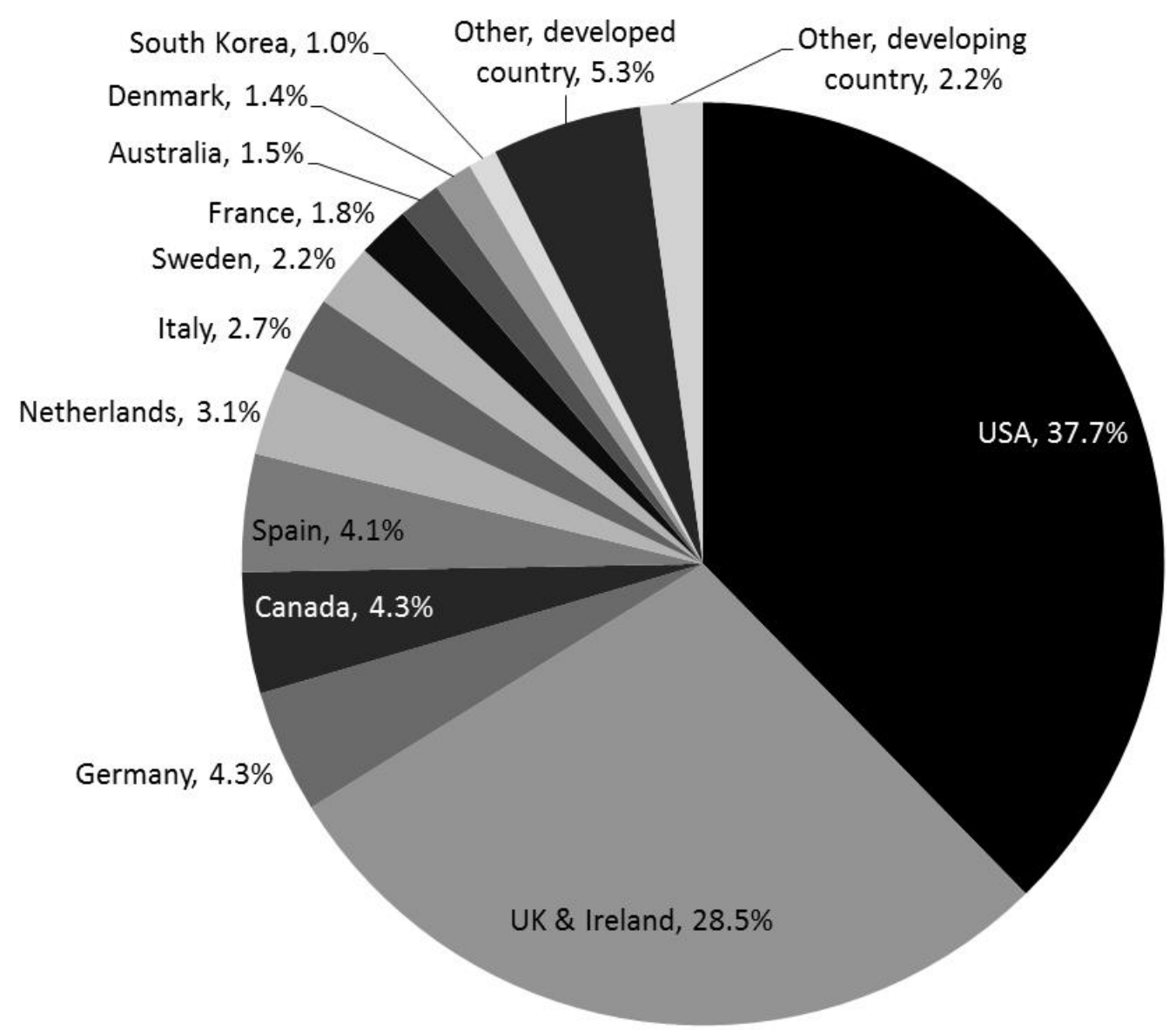

Notes: Results based on 1695 papers published in the top four economic history journals, 19982013. 
Figure 3: Number of citations per article by journal, 1998-2012

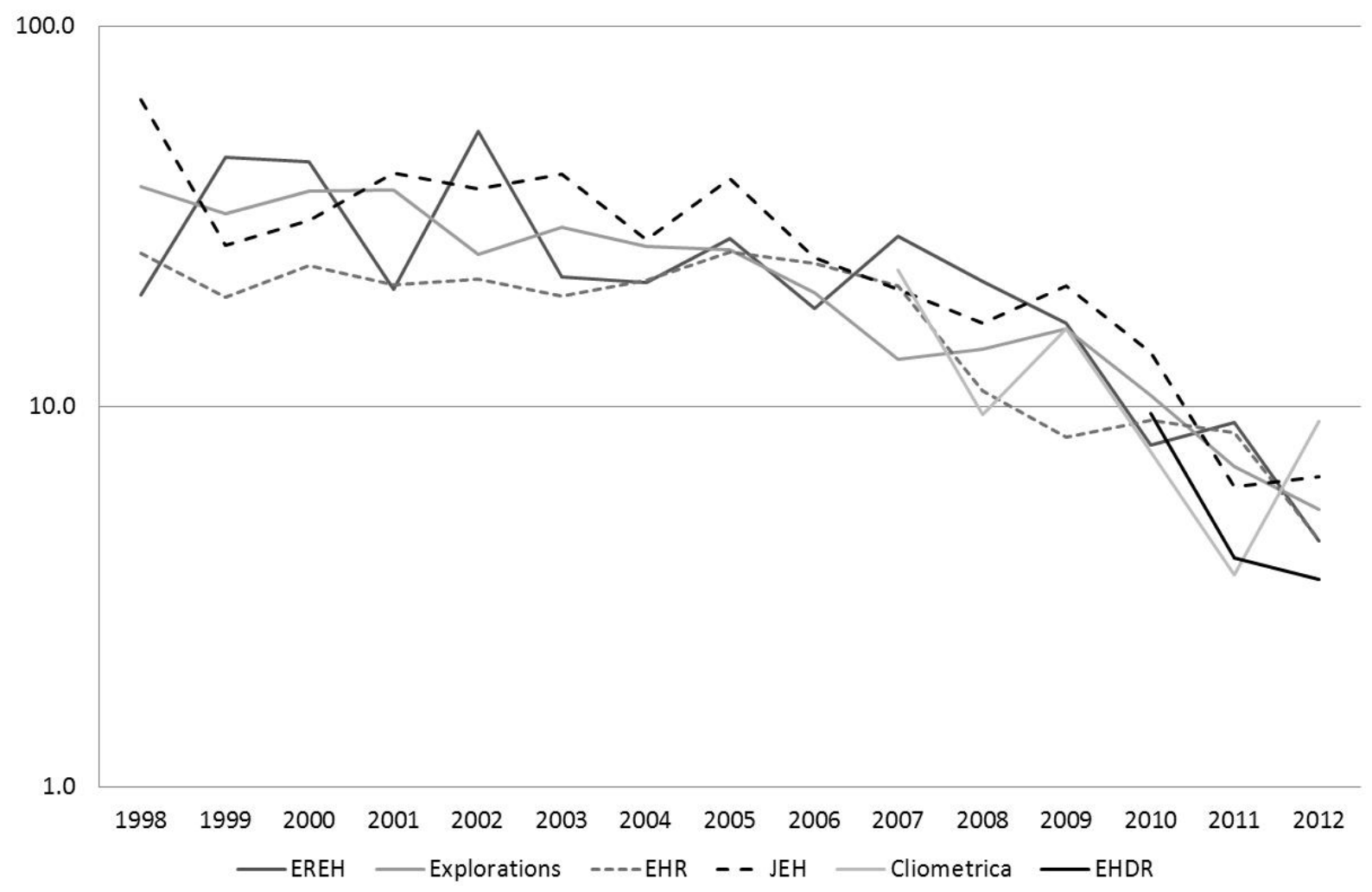

